\title{
NAS Panel Calls for Reform of U.S. Export Controls
}

Current U.S. national-security export controls "fail to promote both military security and economic vitality," according to a 21-member National Academy of Sciences (NAS) panel headed by Lew Allen Jr., former director of the National Security Agency. In fact, the blue-ribbon panel said in the report it issued earlier this year, current U.S. export controls are not only having "an increasingly corrosive effect" on U.S. relations within NATO and other countries, but also are making it harder for U.S. businesses to compete internationally.

Many of the NAS panel's findings and recommendations are similar to those contained in a previous NAS study. Known for its panel chairman, Dale R. Corson, that 1982 study focused on how nationalsecurity export controls affect basic research. However, "the Corson panel indicated, at the time of its report, that there was this much larger element of the problem that they had neither the time nor the resources to address - national security controls on the results of applied research," explains Mitchel B. Wallerstein, project director of the new NAS study. It was to address this larger element that the current 18 -month-long study was conducted.

The new panel estimates that the adverse effects of national-security export controls on high-tech trade currently cost the United States at least $\$ 9$ billion annually. "Our conclusions are not intended to make the recommendation that a greater flow of technology from the West to the East is appropriate," Allen says, "although we feel that more could be allowed at the low-technology end without serious harm." Instead, Allen says, the panel would like to see the United States move toward a more focused and multinational control strategy.

For example, Allen says, "the U.S. alone can control very few items." He points to supercomputers as one of the few areas where the United States has such a dominant position that it can effectively exercise unilateral controls over exports. For an increasing number of other "dual-use" technologies - those having both military and civilian applications - Allen says other Western countries and Japan "are clearly our equal or lead. Therefore, any control system that we conceive of must be multinational."

As a result, Allen says, except for those "precious few" areas where the United States is so far ahead technologically that it can exert unilateral controls, it should focus its control efforts only on those items for which there is agreement with COCOM - the Coordinating Committee on Multilateral Export Controls - whose members include all NATO members (except Iceland) and Japan.

Calling as it does for a strong departure from current administration policy, this recommendation is a particularly controversial one. Right now, U.S. controls prohibit the export of any technologies contained on the Militarily Critical Technologies List - an ever-growing list of virtually every high technology known. (See the MRS BULLETIN, Vol. XI No. 5, 1989, p. 39.) Items are supposed to be deleted from the list when it's found that they are

\section{... the adverse effects of national-security export controls on high-tech trade currently cost the United States at least $\$ 9$ billion annually.}

available to the Soviet Union-either because an equivalent technology has been developed there indigenously, or because the Soviets have access to these products through non-U.S. markets.

Unfortunately, says Steve Gould, an export-controls analyst with the American Association for the Advancement of Science and a consultant to the NAS panel, no time limits were put on the process for decontrolling those technologies found to be available to the Soviets. He says, "The Department of Defense has really sat on that process, so not much has happened."

In fact, he says, the general consensus of the NAS panel was that much of what DOD has been trying to control, in terms of exports, is impractical and amounts to little more than "wishful thinking." By way of example he points to personal computers. "Everybody agrees it would be great to keep them out of the hands of the Soviets," Gould says. But, he points out, it's not feasible to control them when they're manufactured on a massive scale around the world-especially in the Pacific Basin countries like Korea - and sold on a cashand-carry basis. Nevertheless, a subpanel of the NAS export-controls committee on a near-East field trip learned that U.S. customs officials currently spend a great deal of their time attempting to police the export of personal computers.

Another recommendation of the NAS panel is that the controls-evaluation process be streamlined. The panel found that in many cases requests for routine exports took months to a year or longer. This prob- lem is one with which NAS panel member Herbert M. Dwight Jr., chief executive officer of Spectra-Physics, Inc., has personal experience.

Dwight recalls, for instance, bidding on a multimillion dollar order from the People's Republic of China "for relatively pedestrian lasers." Before he could promise shipment, he notes, "we had to go through a cumbersome process to determine whether we could obtain a license." The process lasted more than a year. Says Dwight, because French competitors could obtain their export license in a fraction of the time, they got the order.

Then there's the issue of spare parts and service. Dwight says he also has to go through a lengthy process to obtain export licenses to ship replacement infrared optics to Japanese customers - even those who purchased their original equipment from him. Ironically, he points out, "suppliers from just about anywhere else in the free world are able to ship those same products without licenses."

According to Gould, the licensing process in most other Western countries is very quick - sometimes taking only two or three days - especially for items like personal computers. He says that although the Commerce Department has imposed a 15-day working limit on itself for processing export-license applications going to some noncontroversial destinations, those for other regions - especially developing countries - may take months.

This issue has raised the ire of Rep. Don Bonker (D-Washington), chairman of the House subcommittee with jurisdiction over export controls. He reports that one survey by the American Electronics Association showed that $80 \%$ of exporters wait one to three months for approval to ship goods overseas. "Worse yet," he says, "many exporters report that applications routinely sit in the Department of Commerce for as long as two weeks before the official processing time clock begins, with an additional delay after a decision is made before the paperwork is returned to the exporter."

Another major recommendation by the NAS panel is that the United States consider dropping its requirement that importers of controlled U.S. technologies come back to the United States for a reexport license before they can transfer those products to other destinations. Thomas A. Christiansen, internationaltrade-relations manager for HewlettPackard Co. and a member of the NAS panel, notes that because no other country has such a policy, this encourages foreign buyers to consider shopping outside the United States for equivalent parts or products.

Continued 
Other panel recommendations include: - Eliminating the congressional requirement that items on the Militarily Critical Technologies List be incorporated into the Commerce Department's export-control list because the two lists serve different purposes.

- Re-establishing the Commerce Department as the lead exports controlling agency. Explains Allen, "DOD took leadership [from Commerce] in this because there was the feeling that Commerce was not addressing the problem with sufficient vigor or skill." And while adding that DOD still has a critical role to play in providing advice on which technologies warrant control, Allen says, he considers it "inappropriate" for DOD to continue its active role in the license-review process.

- Simplifying the export-control rules (now 600 pages long) and applications process. At present, the complexity of the rules seem to place small exporters at a competitive disadvantage.
This study "helps make our case that U.S. export controls be streamlined and that the number of controlled items be reduced," says Congressman Bonker. His bill to enact such changes in existing laws

\section{... the panel would like to see the United States move toward a more focused and multinational control strategy.}

passed the House last year but died in the Senate-largely, he believes, because of opposition by the administration, especially the Pentagon. Reintroduced again this year as part of the House leadership's trade bill, Bonker believes his exportcontrols-reform package stands a better chance of passing both houses of Congress.

Previously, the Reagan administration has not been very responsive to outside recommendations for a reform of its export controls. However, Gould believes, because of this track record, there is now increased pressure on the administration to modify its policies. Which may explain why, within a month of publication of the NAS panel's report, the administration let it be known it had begun drafting changes to ease export-control rules and restrictions. The National Security Council is said to be directing a study looking at not only how to reform export controls and but also how to speed interagency deliberations on sticky export issues. Ironically, the impetus cited for these reforms is not the NAS study but the President's call for improved technological and trade competitiveness.

\section{EDITORIAL FOCUS MRIS BULLETIN}

Issue \#5: GLASSES

Multiple articles will describe technological and scientific opportunities in the field of glassy materials with emphasis on silica, phosphate, halide, chalcogenide, and oxynitride glasses.

Editorial Deadline: June 18, 1987

Publication: August 15, 1987

Guest Editor: Frank L. Galeener, Xerox Palo Alto Research Center

\section{Issue \#6: MATERIALS CHARACTERIZATION}

Advances in materials characterization will be explored, including the latest techniques and equipment.

Editorial Deadline: August 3, 1987

Publication: September 30, 1987

Guest Editor: C.R. Helms, Stanford University

\section{Issue \#7: MATERIALS RESEARCH IN CERAMICS}

Recent developments and applications of ceramic materials will be explored.

Editorial Deadline: September 1, 1987

Publication: October 30, 1987

Guest Editor: Robert J. Eagan, Sandia National Laboratories

\section{Issue \#8: MATERIALS UPDATE-POLYMERS}

Technical and feature articles will cover some recent developments in interdisciplinary materials research.

Editorial Deadline: October 15, 1987

Publication: December 31, 1987

Guest Editor: Edwin Thomas, University of Massachusetts 